\title{
Educational Programs Integration as an Important Factor in Enhancing the Professionalism of the Primary and Preschool Teacher under the Conditions of the Higher Education
}

\author{
Natalia Machynska, Halyna Boiko
}

\begin{abstract}
The article covers education integration, application of the integrated approach in developing educational programs for the vocational training of experts in primary and preschool education; different approaches to the interpretation of the concept of «integration» are analyzed. It is noted that the use of interdisciplinary links was a prerequisite for the emergence of an integrated approach in education. The sequence of implementing integrated educational programs in the practice of higher education institutions is determined; the advantages and problems of using integrated educational programs in the vocational training of preschool and primary school teachers are characterized. The most effective ways of developing integrated educational programs are identified; the expediency of using the experience of training specialists for preschool and primary education of the Republic of Poland and Romania is shown.
\end{abstract}

Keywords: integration, integrated approach, vocational training, educational programs, interdisciplinary connections, higher educational establishments.

\section{Introduction}

Education is a social institution which lets everyone improve himself as a person, a specialist and a citizen. Thanks to the teacher's activity, the state educational policy is implemented in creating the intellectual and spiritual potential of the nation, development of national science, technology and culture, preservation and increase of cultural heritage and the constitutional right of Ukrainian citizens to have general secondary education. During the historical and cultural formation of society, thanks to the teacher, the man of the future was formed. The aforementioned issues demand on the problem of professional and pedagogical training of teachers, their professional development and professional competence. Competence 
approach is considered as one of the important conceptual principles, which determines the modern methodology of updating the content of vocational education of future professionals in higher educational establishments.

In the context of Ukraine's integration into the European educational space, reforming the education system under the requirements of the Bologna Process, achieving the goal of modern education requires the transition of the domestic education system to a new concept of education for children and youth. Trends in the implementation of the Concept of the New Ukrainian School (NUS) provide for ensuring the conditions for the realization of the personal potential of each individual who must be capable of independent scientific knowledge, development and implementation of innovative technologies, professionalism, general and professional culture, professional competence development in the higher educational establishment (HEE) in the future education.

The «Agenda for the XXI Century» states that «education is the foundation of sustainable development» and the main tool for creating a humane, equal and attentive to human problems society in which each individual must have his human dignity. Obviously, the main reason for the emergence of education for sustainable development (ESD) is the awareness of the need for changes in the educational paradigm to ensure the further sustainable development of society, economy, and preservation of the environment. Sustainable development education implies the transition to an economically and socially oriented model of learning, which should be based on broad interdisciplinary knowledge, based on an integrated approach to society. It will allow making and implementing decisions at local and global levels which will be aimed at improving the quality of life that does not threaten the ability of future generations to meet their needs (Law of Ukraine, 2018).

To solve these problems we need a teacher / educator who is not only properly trained in various types of pedagogical institutions, but also ready for the lifelong professional growth and improvement of professional skills.

Right now there is a need to train specialists in two related specialties, namely, a preschool teacher and a primary school teacher, which has turned up due to the need to ensure continuity in education, development and personality formation of children at the stage of preschool and primary school age.

The purpose of the study is to analyze educational programs for training future teachers in the certain higher educational establishments of Ukraine, which must be based on the principle of integrated learning; to study the experience of some foreign countries and suggest possible ways of 
its implementation in organizing the educational process at the higher educational establishments of Ukraine.

The task of the research is to analyze the normative-legal base of providing vocational training for the future teachers; to analyze the scientific and theoretical achievements of researchers in this area; to substantiate the feasibility and necessity of developing and implementing an integrated educational and professional training program «Preschool education. Primary education» in the practice of free economic education.

\section{Theoretical basis of the study}

The goal and objectives of the study required to apply several methods. Theoretical methods (analysis, synthesis and comparison) were used to study the evolution of the concepts «differentiation», «integration», «integrated learning», highlight their common and distinctive features; analyze and compare the content of various educational programs built on the integration principle; theoretical methods (generalization and specification) are used to identify certain areas of educational programs in preschool and primary education; empirical methods, in particular the method of pedagogical observation, were used by the authors to study the experience of organizing the educational process in integrated educational programs at the University of Jacz Kokhanowski (Kielce, Poland) and Stefan Cel Mare University (Suceava, Romania).

The concept of «integration» was introduced into science in 1857 by G. Spencer who was linking it to the concept of «differentiation». Integration is dialectically connected with the opposite tendency, namely, the dismemberment and specialization of parts of the whole. If integration seeks to combine all the elements to make the system work to its maximum effect, then differentiation seeks to weaken the relationship between the elements to maximize the efficiency of each of them.

The concept of «integration» in the general scientific aspect is its natural opposition to the concept of «differentiation». There are different approaches to the interpretation of this concept, in particular:

- integration is an appropriate combination and coordination of actions of different parts of the whole system (Dictionary, 2009);

- integration is a process of interpenetration, consolidation, unification of knowledge, which is manifested through the unity with the opposite process of dismemberment, delimitation, differentiation (Antonov, 1989);

- integration is a process of interaction of elements with the set properties that is followed by establishment, complication and strengthening 
of essential communications between these elements on the basis of sufficient grounds; as a result, an integrated object (integral system) with qualitatively new properties is formed; the individual properties of the initial elements are preserved in the structure (Kostyuk, 1998);

- integration is a process and result of creating the inextricably linked, unified issues; the process of convergence and connection of sciences, which operates along with the differentiation process; it is the highest form of interdisciplinary relations embodiment at a qualitatively new level of education (Kozlovska, 1999);

- integration (from the Latin. Integrum - whole, integratio restoration) is the state of integration of individual parts and functions of the system as a whole, as well as the process leading to such a state; unification and coordination of actions of different parts of the integral system (Law of Ukraine, 2018).

Therefore, the analysis of different definitions of the concept «integration» allows us to state that integration is considered from the standpoint of interaction, unification, interpenetration, convergence, restoration of unity of two or more systems.

Sustainable development is such kind of development that enables the needs of present and future generations to be met. This is a balanced development of the country and regions, in which economic growth, material production and consumption, as well as other activities of society occur within the limits determined by the ability of ecosystems to recover, absorb pollution and support the lives of present and future generations (Law of Ukraine, 2018).

The obligatory result of such unification should be the formation of a new integral system, which is characterized by new properties and relationships between all structural elements.

Integrated Learning (Adapted from the Natural Curiosity: A Resource for Teachers University of Toronto OISE) is learning that is based on an integrated approach. In this regard, education is considered through the prism of the general picture, and is not divided into separate disciplines.

The concept of integration in education is quite multifaceted and may include changes that take place at different levels. The formation of unity between the individual elements is common to any integration process and is peculiar by identifying common features between them.

There are the following degrees of integration:

- subject stage (among objects of research or complex problems);

- problematic stage (among research methods);

- horizontal stage (in natural sciences);

- vertical stage (between groups of sciences). 
Interdisciplinary links play an important role in education integration and the emergence of integrated learning. Their psychological and pedagogical justification was represented in Man as a Subject of Education (section «Association of Ideas») by K.D. Ushynsky, where the author clarifies the need of interdisciplinary links implementation in terms of psychology.

In the twentieth century Yu. Samarin, B. Ananiev, the psychologists, Yu. Babansky, I. Lerner, V. Onyschuk, and M. Skatkin, the teachers, made a significant contribution to the development of the theory of interdisciplinary relations. Thus, in particular, in the 1960s, interdisciplinary links were considered in various aspects:

- as a didactic means of improving learning effectiveness;

- as a condition for the development of cognitive activity and independence of students in educational activities;

- as a means of implementing scientificity principle.

It was during this period that research on interdisciplinary links in terms of intensifying learning and raising its scientific level was carried out, and some attempts to substantiate the concept of interdisciplinary links as a didactic principle of learning were made. In the 1970s, interdisciplinary connections become one of the central topics in didactics. Therefore, the research results are reflected in the definition of the main areas of learning process improvement. They reveal the methodological function of interdisciplinary links, namely:

- the scientific level of education is increased;

- the implementation of such links contributes to the involvement of students in the systemic method of thinking, expands the scope of knowledge, combining elements of knowledge of different disciplines;

- interdisciplinary links provide a system in the organization of subject teaching, encourage teachers to self-education, creativity and interaction with other subject teachers.

The emergence of integrated learning is the result of a high level of interdisciplinary links implementation. Being a new phenomenon of the educational process, integration is based on the areas of knowledge, scientific ideas, concepts that are common for several subjects. Integrated learning is a necessary component of updating the national education system, which is based on the following principles: accessibility, scientificity, sequences, systematicity, integrity, logic, vertical themes. It is an integrative approach in education that can return a child to the joy of learning, «... when a person wants to learn, when he/she goes to school, reads, writes, learns and feels joy and human pride at the same time. Learn, because learning is good and makes you happy» (Sukhomlynsky, 2016, p. 349). 
The main goal of every educational reform, including the current one, is the implementation of the provisions of the Concept of the New Ukrainian school aimed at the improvement of education quality. Which factors ensure the quality of primary education?

Let's select the most influential of them:

- full and timely coverage of all children of primary school age;

- versatile use of the achievements of the preschool period;

- modernization and rehabilitation of the educational environment;

- introduction of methods of personally and competence-oriented teaching, education and development of younger students;

- manufacturability of teaching methods;

- monitoring of the educational process;

- adequate training of teachers, etc. (Concept, 2016).

\section{Discussion}

An essential feature of pedagogical work lies in the fact that this activity is based on a constant continuous process of interaction of different categories of people. It strengthens the role of personal relationships in teaching and emphasizes the importance of moral aspects. Its result is also specific as a person who has mastered a certain part of social culture, is capable of social self-development and fulfillment of certain social roles.

The Professional Standard for Teachers (2020), which should be introduced into the Ukrainian education system since 2021, provides for the formation of various groups of general and professional competencies to ensure the effective organization of the educational process. We consider that among the professional competencies defined by the Ministry of Education there are those that should be inherent in both primary and preschool education. In particular, it is A2. Subject competence, which involves the ability to use subject knowledge in the educational process and the ability to integrate subject knowledge from different educational areas (Professional Standard, 2020).

Teacher's work is a type of activity, which is peculiar for its psychological and pedagogical influence on students, taking into account their age and individual characteristics, needs and interests, hobbies, spiritual world, but at the same time, purposeful management of learning and personality development (2015, p. 285).

The Standard of Higher Education (2019) for specialty 012 «Preschool education», area 01 «Education / Pedagogy» for the first (bachelor's) level of higher education, section «Special professional competencies» states: Ability to enhance children's basic qualities of personality 
Trends and Prospects of the Education System and Educators' Professional ...

(arbitrariness, independence, creativity, initiative, freedom of behavior, self-awareness, selfesteem) in early and preschool age is more than significant (2019).

A teacher is a specialist who has special training and professionally conducts educational work in various educational systems. Pedagogical activity is a professional activity aimed at the formation and development of the pupils' personality.

Professionalism is the ability acquired in the process of educational and practical activities; it ensures the competent performance of professional duties, certain level of skill and art of performing a specific type of tasks, according to different levels of their complexity (2015).

Professional competence is a basic characteristic of a specialist's activity; it includes both semantic (knowledge) and procedural (skills) components and has the main essential features, namely: mobility of knowledge, flexibility of methods of professional activity and critical thinking. Researchers have proposed the following understanding of professional and pedagogical competence: it is a complex multilevel stable structure of one's mental traits, which is formed due to the integration of experience, theoretical knowledge, practical skills, significant personal qualities for the teacher and has outlined essential features (mobility, flexibility and critical thinking). These changes set new requirements for the work of our fellow citizens: the quality of their training and professional competence, the level of socio-professional mobility, competitiveness in the labor market and in various areas of production (Concept, 2011).

The purpose of the integrated educational and professional program «Primary education. Preschool education» for Bachelor's level is enhancing future teachers' professional competence as well as personality traits that will be manifested in the ability to solve complex specialized and practical problems in professional and pedagogical activities involving theoretical principles and methods of pedagogy, psychology and individual teaching methods and are characterized by complexity and uncertainty of conditions (Pavlo Tychyna Uman State Pedagogical University, 2019).

The main goals of the educational-professional program «Preschool education» (Kamyanets-Podilsky National Ivan Ogienko University, 2020) for Bachelors, specialty 012 «Preschool education» are the following: training for development and education of children of early and preschool age in educational institutions and families so that they will be able to solve complex specialized tasks, characterized by complexity and uncertainty of conditions by applying the theory and methods of preschool education; to form professional competencies for the implementation of the concept of «New Ukrainian School», training of the future primary school teachers in the educational areas defined by the State Standard of Primary Education, at 
a level consistent with professional and academic qualifications, perform professional functions in inclusive education, organize speech therapy work with children.

This program is integrated; it provides training for two related specialties: bachelor of preschool education and primary school teacher; bachelor of preschool education and assistant teacher-speech therapist.

\section{Results}

The basis of pedagogical skills is professional competence. On the one hand, the teacher's knowledge is directed at the disciplines he/she teaches, and on the other hand, at the students, whose psychology he/she must know well. While preparing for the lesson, the teacher considers its content, methodology, perception peculiarities of students of this age, class, and their own capabilities. Consequently, professional competence is the knowledge of the subject, methods of its teaching, pedagogy and psychology. The task of the higher educational establishment is to help students master the basics of pedagogical skills for a conscious and productive beginning of professional activity. It involves enhancing humanistic orientation, mastery of thorough knowledge, development of pedagogical abilities, basics of interaction, preparation for professional analysis of a variety of pedagogical situations. In our opinion, all those aspects should be reflected in the student's professional readiness, which will have the maximum effect in the integration of educational programs.

In the Pedagogical Competence Concept (2011), researchers propose a model of pedagogical competence that integrates different types of competencies, revealing the general abilities of the teacher in different aspects of the pedagogical process. We are talking about cognitiveintellectual, diagnostic, design, organizational, prognostic, informational, stimulating, assessment, analytical, psychological, social, civic, communicative, reflective, creative, methodical, research competence, etc.

We believe that some competencies are simply necessary for professionals who will receive training in the content of the integrated educational program «Preschool Education. Primary education». They are the following:

- social competence is the teacher's ability to adequately assess the surrounding reality on the basis of complete knowledge about it, which allows to understand the basic laws of the social situation, the ability to find information in an uncertain situation and confidently build their behavior to balance their needs, expectations, meaning and requirements of social reality, the ability to satisfy desires, based on norms; 
- psychological competence means the teacher's ability to adequately assess their own abilities, capabilities, level of demands, psychological characteristics; choose the most effective behavior in a given situation; to regulate one's own emotional states, to overcome critical pedagogical situations, etc;

- prognostic competence is the teacher's ability to determine the direction of their activities, their specific goals and objectives at each stage of educational work, and to predict the final result (Concept, 2011; KowalczukWaledziak et al., 2019).

Analysis of these educational and professional programs makes it possible to argue that the professional readiness of the student, the future specialist of preschool and primary education is an integrative personal quality and an essential prerequisite for effective activity after graduation. Student's professional readiness helps the young specialist to be successful in performing their duties, apply knowledge, experience, maintain self-control and restructure in the event of unforeseen obstacles in the educational process of preschool and primary school.

The fulfillment of the tasks of the educational process aimed at training specialists in integrated educational programs depends on a combination of many interrelated and interdependent factors. We believe that the professional training of primary school teachers - preschool educators should be organized in order to integrate into the European educational and scientific space by combining the academic and applied components of education on a research and innovation basis. Development of integration educational programs is a new direction in professional training of future specialists in pedagogical education. Using foreign experience and preserving the unique national educational feature, we offer some areas of developing educational programs.

The first area. It is expedient to involve researchers not only in a specific professional field, but also in the development of educational programs for the related professions. We believe that such cooperation will ensure the optimal selection of competencies that future professionals should master. It is also important to coordinate the content of educational programs with employers' associations and adjust them according to the needs of the professional area.

The second area. In the process of educational programs approbation it is necessary to involve university students in carrying out scientific researches, beginning from the first year of study. Selection criteria should be such qualities of applicants as analytical and critical thinking, readiness for experimental actions, internal mobility, motivational focus on obtaining results. 
The third area. Employers of those educational institutions that serve as a basis for professional practical training of the future teachers of preschool institutions and primary school should be involved in the development of educational programs. The most expedient example can be the heads of educational complexes «institution of preschool education comprehensive schook.

The fourth area. In the process of approbation and development of integrated educational programs it is important to introduce students' exchange programs within domestic and foreign higher education institutions. Based on the studied and tested content of the educational process organization at the foreign educational institutions it is significant to develop the ways to implement the experience gained in the curriculum.

The fifth area. At the stage of educational program development it is necessary to ensure adjustment and coordination of the content of education, curricula and programs with employers and university students at different levels. The main goal is to focus on the main components of professional and pedagogical competence, development and implementation of new courses that will contribute to the formation of professional and pedagogical competence of future teachers of preschool and primary education.

A separate aspect of developing educational programs on the principle of an integrative approach is to expand the opportunities for involvement of people with special educational needs in educational programs. We believe that the creation of an educational program of professional training on the basis of an integrative approach will contribute to the maximum implementation of the individual trajectory of each student, which will ensure the mobility of higher education, as well as expand opportunities for educational services for people with special needs. We are also convinced that it is expedient to envisage the possibility of introducing integrated educational programs for simultaneous study in several educational programs in a number of higher education institutions, which provides for the active introduction of distance learning (development of ecourses) for people with special needs, in particular.

\section{Conclusions}

Integration, integrated approach, integration in education is an alternative direction of developing educational programs for training specialists in two related specialties: preschool and primary education. We believe that this approach will contribute to the effective formation of professionalism of primary school teachers and educators of preschool 
education in a higher educational establishment. Professionalism, as an integrated collective concept, covers a set of theoretical knowledge, practical experience and professional skills achieved by a person, which is determined by professional competence. It is the foundations of professionalism that are formed in the conditions of higher education, and depend on the skills of teachers and researchers. We believe that it is advisable to focus on the development of joint educational programs based on programs of foreign educational institutions, as well as the development of their own experimental educational programs, where it is advisable to provide internships for foreign applicants, introduce the practice of participation of leading higher education institutions in the educational process of free economic education, to ensure the connection of the university educational process with additional and corporate training in others.

In this context, we focus on studying the experience of training specialists for primary and preschool education at the University of Jan Kokhanowski (Republic of Poland) and the University of Stefan Cel Mare (Romania), which was being studied by the authors from 2017 till 2019 under a cooperation agreement, concluded between the aforementioned institutions of higher education and Ivan Franko National University of Lviv.

Prospects for the further research are seen in the systematic training of higher education professionals (development of training programs and training sessions, theoretical and practical seminars, professionally-defined internships), which should become a prerequisite for organizing the educational process in higher education institutions.

\section{References}

Antonov, N.S. (1989). Integrative learning function. Kyiv: «Osvita» Publishing House.

Busel, W. T. (Ed.) (2009). Large explanatory dictionary of the modern Ukrainian language (with appendix, supplement on CD). 7th edition. Kyiv: Irpin: «Perun» publishing house.

Draft professional standard for the professions «Primary School Teacher», «Secondary School Teachen». (2020). Ministry of Education and Science of Ukraine. https://mon.gov.ua/ua

Kostyuk, N.T. (1998). Objective conditionality and dialectic of integration of modern scientific knowledge. Kyiv: «Vyshcha Shkola» publishing house.

Kozlovska, I.M. (1999). Theoretical and methodological aspects of integration of knowledge of students of vocational school. In: Honcharenko, S. U. (Ed.). Didactic bases: monograph. (pp. 32). Lviv: «Svit» publishing house.

Kowalczuk-Waledziak, M., Lopes, A., Underwood, J., Linda, D., \& Clipa, O. (2019). Meaningful time for professional growth or a waste of time? A study 
in five countries on teachers' experiences within master's dissertation/thesis work. Teaching

Education. https://www.tandfonline.com/doi/full/10.1080/10476210.2019. $\underline{1649649}$

Official site of Kamyanets-Podilsky National Ivan Ogienko University. http://kmd.kpnu.edu.ua/navchalni-dystsypliny-kafedry.

Official site of Pavlo Tychyna Uman State Pedagogical University. https://fdo.udpu.edu.ua/osvitni-programy.

Approval of the Higher Education Standard (2019) on a specialty 012 «Preschool education» for the first (bachelor's) level of higher education.

https:/ / mon.gov.ua/storage/app/media/vishchaosvita/zatverdzeni\%20standarty/2019/11/22/2019-11-22-012doshkilnaB.pdf.

Strategy of Sustainable Development of Ukraine until 2030 (2018). http://search.ligazakon.ua/1 doc2.nsf/link1/JH6YF00A.html

Pavlova, O.V. (Ed.). (2015). Continuing adult education. Glossary of Terms. 2nd ed., Corrected. and ext. SPb .: INOV.

Sukhomlynsky, V. (2016). I will tell you a fairy tale. Philosophy of children; compiled by Sukhomlynska O.V. Kharkiv: «Shkola» publishing house.

The concept of pedagogical competence of future teachers in the system of degree training of primary education specialists (2011). Khmelnytsky Humanitarian and Pedagogical Academy: http://www.kgpa.km.ua/?q=node/233

The concept of the New Ukrainian School (2016).

https://mon.gov.ua/storage/app/media/zagalna $\% 20$ serednya/novaukrainska-shkola-compressed.pdf 